\title{
Rape embryogenesis. V. Accumulation of lipid bodies
}

\author{
TERESA TYKARSKA
}

\author{
Laboratory of Electron Microscopy, Institute of Botany, Warsaw University, \\ Krakowskie Przedmieście 26/28, 00-927 Warsaw, Poland \\ (Received: November 1, 1986. Revision accepted: May 25, 1987)
}

\begin{abstract}
In embryo of winter rape var. Górczański lipid bodies have been observed in the light microscope starting from two-celled proembryo. Their number and size increase in the course of embryogenesis, especially since greening of endosperm and embryo. Lipid bodies, either single or in clusters, are present in all embryo cells, the clusters occur in various parts of the cytoplasm. During embryo maturation lipid bodies move and locate in a number of layers by the cell wall. At the same time their appearance change. Typical storage lipids originate. Lipid bodies are unevenly distributed within the embryo: their number and size decrease along the embryo axis from its part below cotyledons towards root apex. Moreover, they are histologically diversified: the biggest are located in epidermis and cortex, whereas the smallest - in central cylinder. In columella there are fewest lipid bodies.
\end{abstract}

Key words: rape embryoqenesis, storage material, lipid hodies

\section{INTRODUCTION}

In many oil seeds starch originates the first. In the course of maturation it declines and is replaced by oil (Svieshnikova 1954). In mature rape seeds protein and lipid bodies are stored. Starch has already been observed in a two-celled rape proembryo. The number and size of starch grains increase till the end of embryo development which takes place in green seeds. Starch gradually declines when the seed coat colour changes from green to brown. In mature embryos from dry seeds starch is lacking (Tykarska 1982).

Lipids in rape seeds have been studied mainly by biochemical methods. 
Mostly quantitative changes and chemical composition of lipids in the course of seed development and maturation of various rape cultivars have been analysed (Zeman and Kratochwil 1967, Fowler and Downey 1970, Wiązecka and Krzymański 1970, Norton and Harris 1975). Many studies carried out by means of electron microscopy consider formation of lipid bodies in seeds of different plants (Frey-Wyssling et al. 1963 - rape, Bergfeld et al. 1978 - mustard. Adams et al. 1983- soybean), whilst anatomical and developmental descriptions of formation and location of lipid bodies in embryo cells are scarce. Schultz and Jensen (1968a, b) have studied the development of young Capsella embryos, while Kavetskaya (1960) - the dynamics of storage reserve accumulation in rape.

In mature rape embryo the biggest and the most numerous lipid bodies are found in cotyledons and in the part of hypocotyl below them, whereas in columella and in outer layers of hypocotyl-root boundary they are the fewest. Lipid bodies are located mainly by the cell wall, while protein bodies, surrounded by a single layer of lipid bodies, are located in the cell -centre (Kuraś 1984), similar to other ol seeds like mustard (Rest and Vaughan 1972) and soybean (Bair and snyder 1980).

In the present paper the location and transformations of lipid bodies during of embryo development have been determined with the electron microscope. Fixation of lipid bodies is usually difficult, therefore various methods have been applied.

\section{MATERIAL AND METHODS}

Zygotes and embryos up to heart stage were pressed out of living Brassica napus var. Górczański ovules. Then they were stained with Sudan III and Sudan III-IV mixture in $70 \%$ ethanol (Lison 1960) or Sudan Black B in $85 \%$ propylene glycol (Chiffelle and Putt 1951). Cut-off globular heart and torpedo embryos, as well as whole or threefold divided axes of older embroys were fixed in:

1) Levitsky's mixture (La Cour et al. 1958), i.e. 0.5-5 chromformalin $1 \% \mathrm{CaCl}_{2}$, for $24 \mathrm{~h}$ at $4{ }^{\circ} \mathrm{C}$ and postfixed in $5 \% \mathrm{~K}_{2} \mathrm{Cr}_{2} \mathrm{O}_{7}$ for $1-20$ weeks at room temperature. $5 \mu \mathrm{m}$ sections were then stained with Sudans.

2) In $2 \%$ glutaraldehyde in phosphate-citrate buffer $(\mathrm{pH} 6.8)$, postfixed in $1 \% \mathrm{OsO}_{4}$ embedded in epon or paraffin. Next they were cut with ultramicrotome into semi-thin sections (ca. $250 \mathrm{~nm}$ ).

3) The material was stored for 4-6 months in $10 \%$ formalin $-1 \% \mathrm{CaCl}_{2}$ (formal-calcium, Baker 1946) then osmed and embedded in epon. Semi-thin sections were stained with toluidine blue or not stained at all. 


\section{RESULTS}

EVALUATION OF THE METHODS

Staining of proembryos and embryos pressed out in toto with Sudans appears to be an appopriate method. Lipid bodies have been clearly visible even in heart embryos.

In the material fixed in Levitsky mixture lipid bodies are apparent since the eighth week of postfixation in $\mathrm{K}_{2} \mathrm{Cr}_{2} \mathrm{O}_{7}$. However, from the material fixed in $\mathrm{GA}$ and postfixed in $\mathrm{OsO}_{4}$ a better picture has been obtained (Figs. 9, 10, 12-15). Embryos long-stored in $10 \%$ formalin-1\% $\mathrm{CaCl}_{2}$ are fixed similarly (Fig. 11). The difference in the fixation of lipid bodies in GA between embryo development and its maturation stages (described below) takes also place in the material fixed in formal-calcium.

LIPID BODIES IN EMBRYO

Embryo development

In two-celled proembryo small lipid bodies slightly stained with Sudan III-IV mixture and with Sudan Black B are visible. They occur mainly in a basal cell (Fig. 1).

Well-stained lipid bodies appear in suspensor cells of a two-celled proper proembryo. They are mainly accumulated in basal cells of suspensor (Fig. 5), while in apical cells they are smaller and fewer. In proper proembryo they are hardly visible till the stage of dermatogen differentiation, when single, small and only slightly stained lipid bodies occur in all cells (Fig. 2); the best visible ones are in dermatogen. Since then they are always present in the embryo. The number and size of lipid bodies increase and from the torpedo stage the bodies are visible without immersion oil.

In semi-thin heart-shaped embryo sections small lipid bodies are mostly single, though they sometimes occur in 3-4-body groups. They are, however, more numerous in the apical part (Fig. 3).

In all torpedo embryo cells considerably more and bigger lipid bodies occur. However some diversity is apparent. The biggest and the most numerous lipid bodies are found in primary cortex (Figs. 6, 8) and below shoot apex (Fig. 7). They are slightly smaller but also numerous in central cylinder. Considerably fewer lipid bodies occur in root below the apex, fewest in the intermediate layer and in columella (Fig. 4). Lipid bodies are located in a single layer or in groups, mainly by the cell wall (Figs. 7, 8).

At the final embryogenesis stage there is already a great number of lipid bodies in the whole embryo (Figs. 9-15). They are still spherical and located in one or several layers by the cell wall. Clusters of lipid bodies 

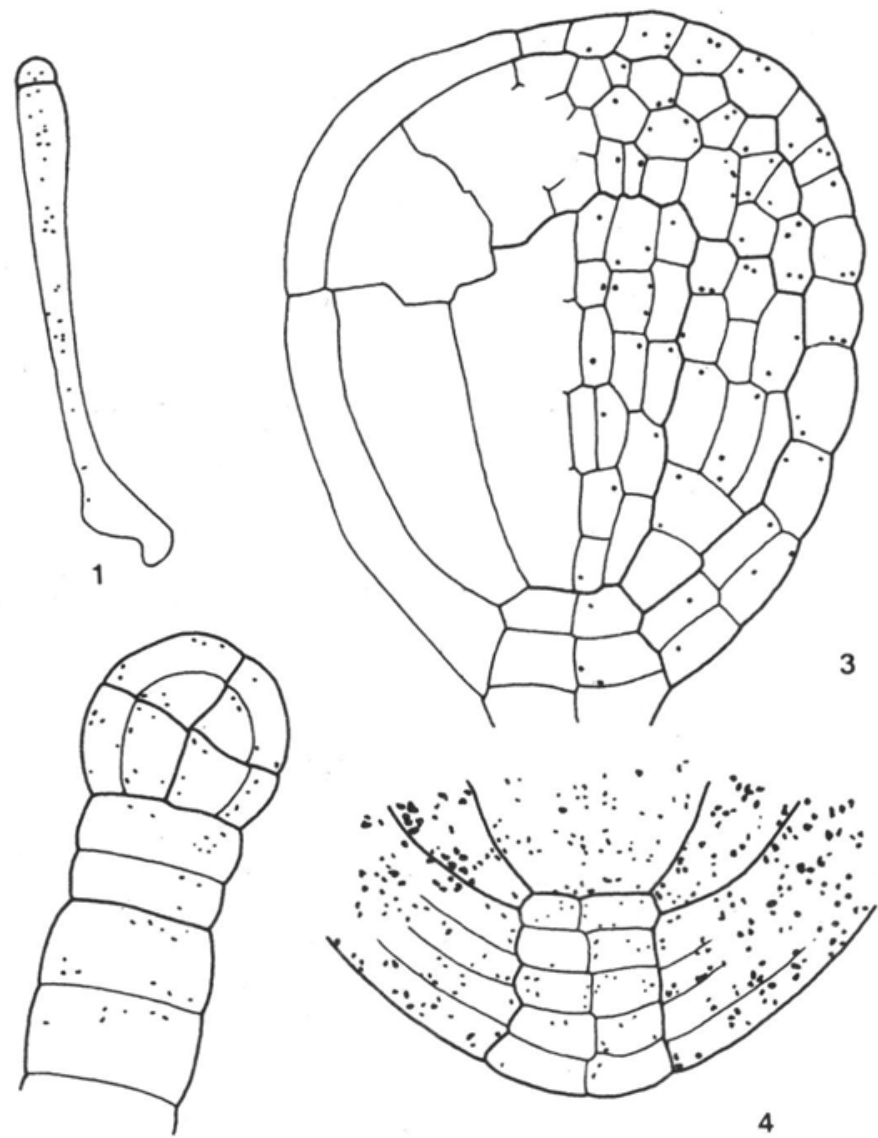

3

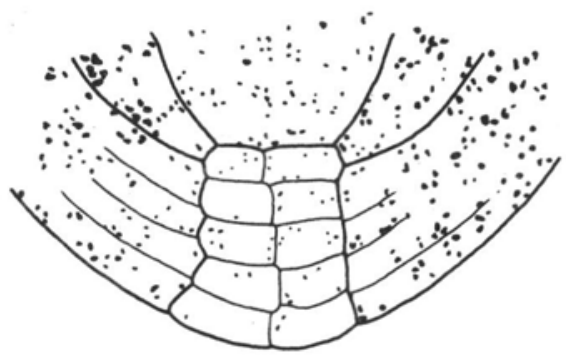

4

2

Figs. 1-4. Initial stages of embryogenesis. Lipid bodies as black points. Fig. 1. Two-celled proembryo. Fig. 2. Proembryo with differentiated dermatogen. Fig. 3. Embryo at the transient stage between globular and heart stages. Fig. 4. Root apex of torpedo embryo

often squeeze in between vacuoles or forming protein bodies. Such a pattern is especially characteristic of hypocotyl cortex (Figs. 10, 11).

Along the embryo axis a regularity in the distribution of lipid bodies is visible. Their number and size decrease from the part below cotyledons towards root apex (Fig. 21). The biggest lipid bodies occur just below plumula and in upper hypocotyl (Figs. 9-11). In its centre and in the bottom part they are slightly smaller, while in root much smaller and fewer (Figs. 13, 21).

Great differences between single histological layers are visible perpendicullary to the embryo axis. Lipid bodies are the most numerous and the biggest in epidermis and primary cortex (Figs. 11, 12). There are markedly fewer in the cells of central cylinder (Figs. 13, 14) and the fewest in the central strand of metaxylem cells (Figs. 14, 15). In cortex and in hypocotyl epidermis 
PLATE I

Fig. 5. Proembryo suspensor (two-celled apical part) stained with Sudan III and IV, $\times 1000$. Lipid bodies as black dots. Figs. 6-8. Torpedo stage. Longitudinal section through the axis of embryo fixed in $\mathrm{GA}$ and postfixed in $\mathrm{OsO}_{4}$. Fig. 6. Embryo axis $\times 300$. Fig. 7. Shoot apex $\times 1000$. Fig. 8 . Cells of primary cortex and central cylinder in the embryo centre, $\times 5000$

PLATE II

Embryo at the final embryogenesis stage. Lipid bodies stained black with osm while fixed in GA, Fig. 11. except - where fixed for 4 months in $10 \%$ formalin $-1 \% \mathrm{CaCl}_{2}$. Semi-thin section stained with $1 \%$ toluidine blue in borax. Fig. 9. Shoot apex $\times 500$. Fig. 10. Root cortex - central cylinder boundary in the embryo axis part below cotyledons $\times 1000$. Fig. 11 . Cells of epidermis and primary cortex in the hypocotyl half-length. In subdermatogen myrosin idioblast is visible, $\times 1000$. Fig. 12. Hypocotyl-root boundary - the beginning of the I cap layer, $\times 1000$. Fig. 13. Primary cortex - central cylinder boundary in the upper root part, $\times 1000$. Fig. 14. Central cylinder cells with distinct strand of metaxylem cells in embryo root, $\times 1000$. Fig. 15 . Root apex $\times 500$

PLATE III

Fig. 16. Fragment of shoot apex in green seed. Material fixed in $0.5-5 \mathrm{CrF}-1 \% \mathrm{CaCl}_{2}$ and postfixed in $5 \% \quad \mathrm{~K}_{2} \mathrm{Cr}_{2} \mathrm{O}_{7}$ for 10 weeks. $5 \mu \mathrm{m}$ paraffin section stained with Sudan Black B. Figs. 17-20. Lipid bodies in maturing embryos. Semi-thin epon sections fixed in $\mathrm{GA}$ and $\mathrm{OsO}_{4}, \times 1500$, Fig. $19-\times 1750$. Fig. 17. Fragment of embryo subapical shoot part from late green seeds. Fig. 18. Cortex cells in the half-length of embryo axis from late green seeds. Fig. 19. Fragment of primary cortex - central cylinder boundary in the half-length of embryo axis while seed coat becomes brown. Fig. 20. Fragment of cortex cells at embryo hypocotyl-root boundary in green-brown seed

lipid bodies form large clusters (Figs. 11, 21h), whereas in the root part they occur as a single layer by the cell wall (Figs. 13, 21r).

At the hypocotyl-root boundary lipid bodies occur in greater number in dermatogen and subdermatogen than in inner cortex cells where storage protein accumulate.

Within cortex cells, one may distinguish slightly bigger myrosin idioblasts with spherical homogeneous protein bodies. There is a single layer of lipid bodies by the wall of myrosin cells. Inside these cells small groups of lipid bodies occur (Fig. 11). In shoot and root apices numerous lipid bodies are also found. Moreover, in shoot apex they are bigger. The tiniest lipid bodies are observed in the intermediate layer and in columella where they are often clustered (Fig. 15). In lateral parts of the cap lipid bodies are much more abundant.

\section{Embryo maturation}

In still green seed, after the completion of cell divisions, lipid bodies change their appearance. They are not as elegant and regularly spherical as they were before, because distinct border between them and slightly lighter cytoplasm disappears (Figs. 17, 18). Lipid bodies in shoot and root 
PLATE I

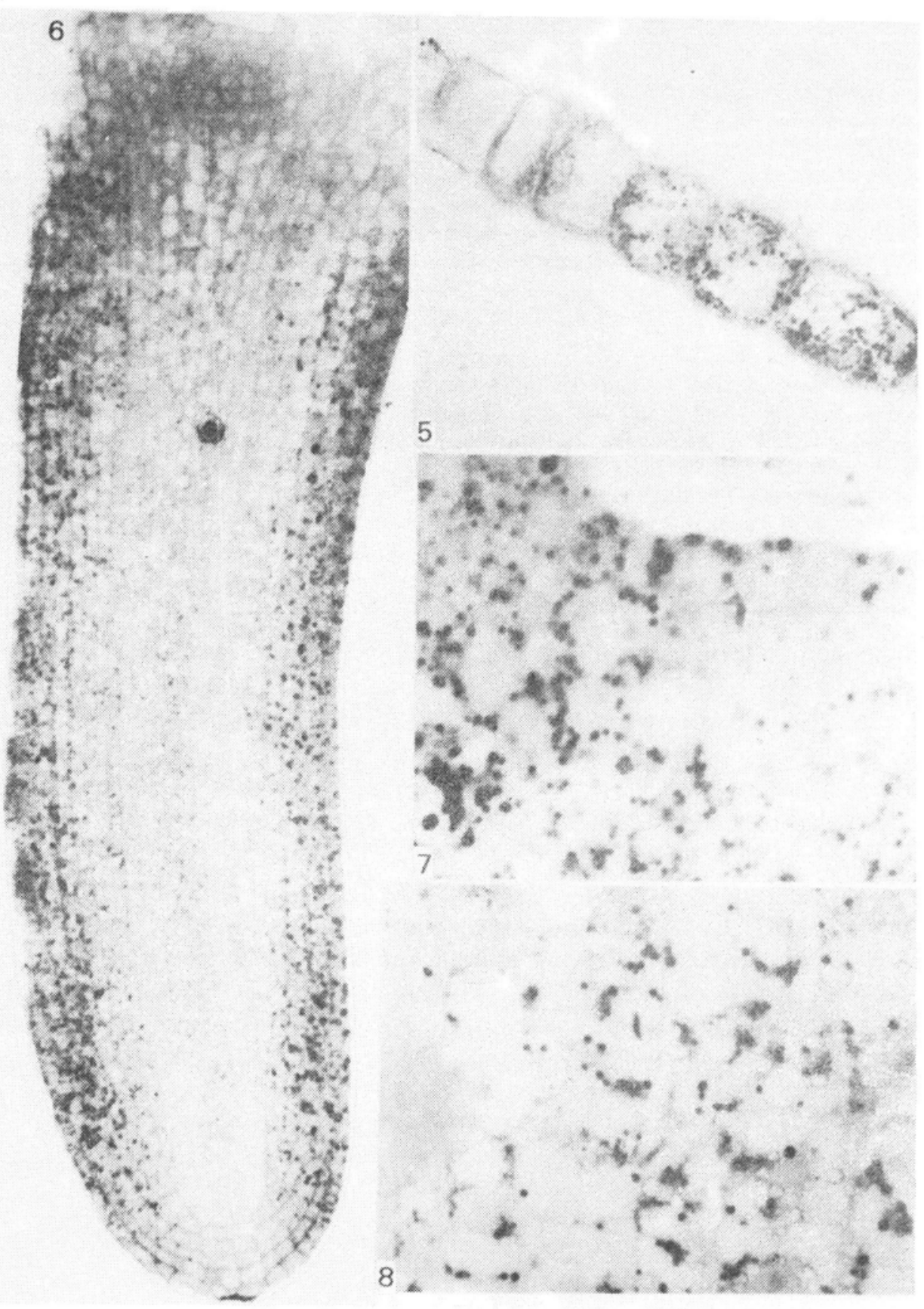


PLATE II

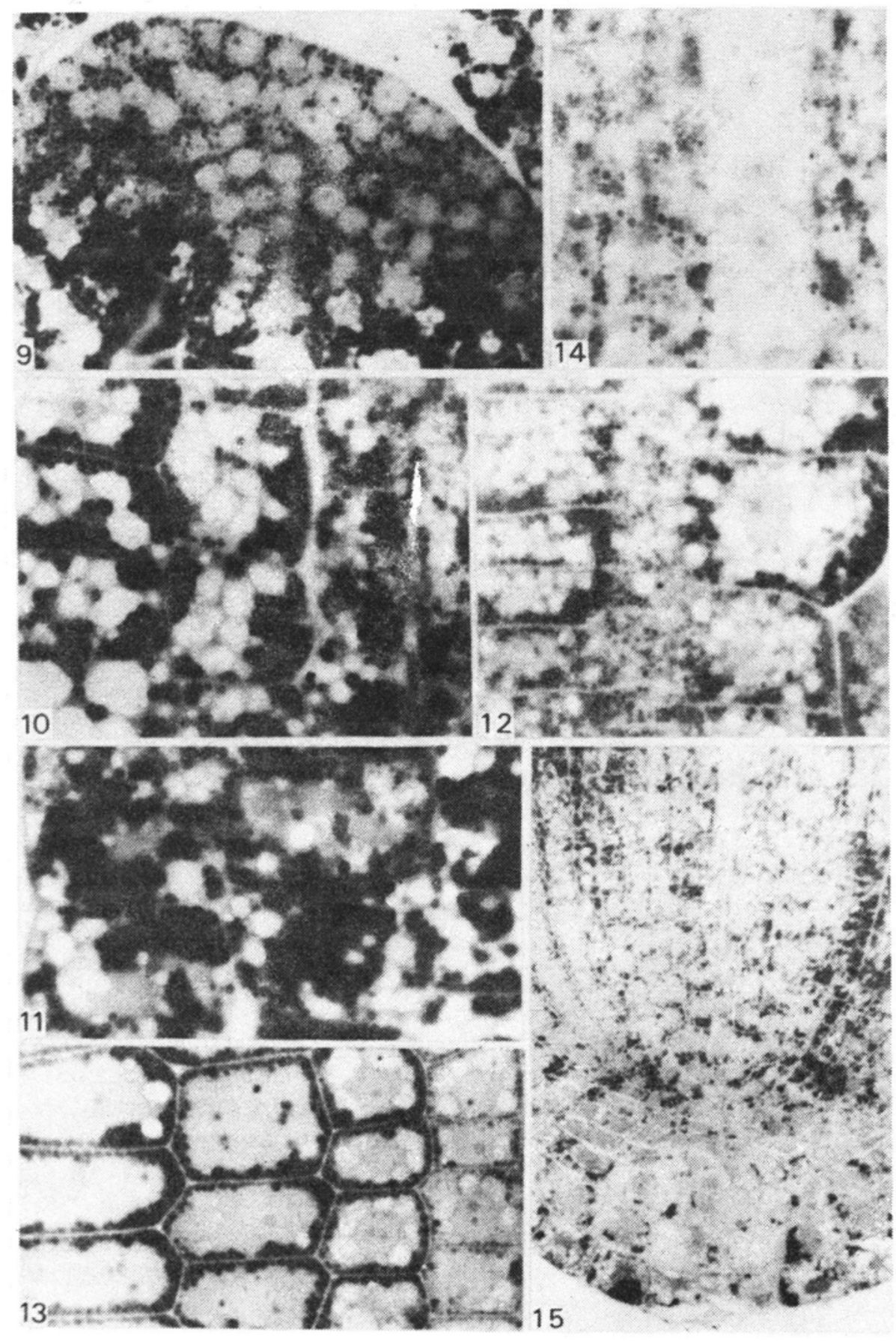


PLATE III
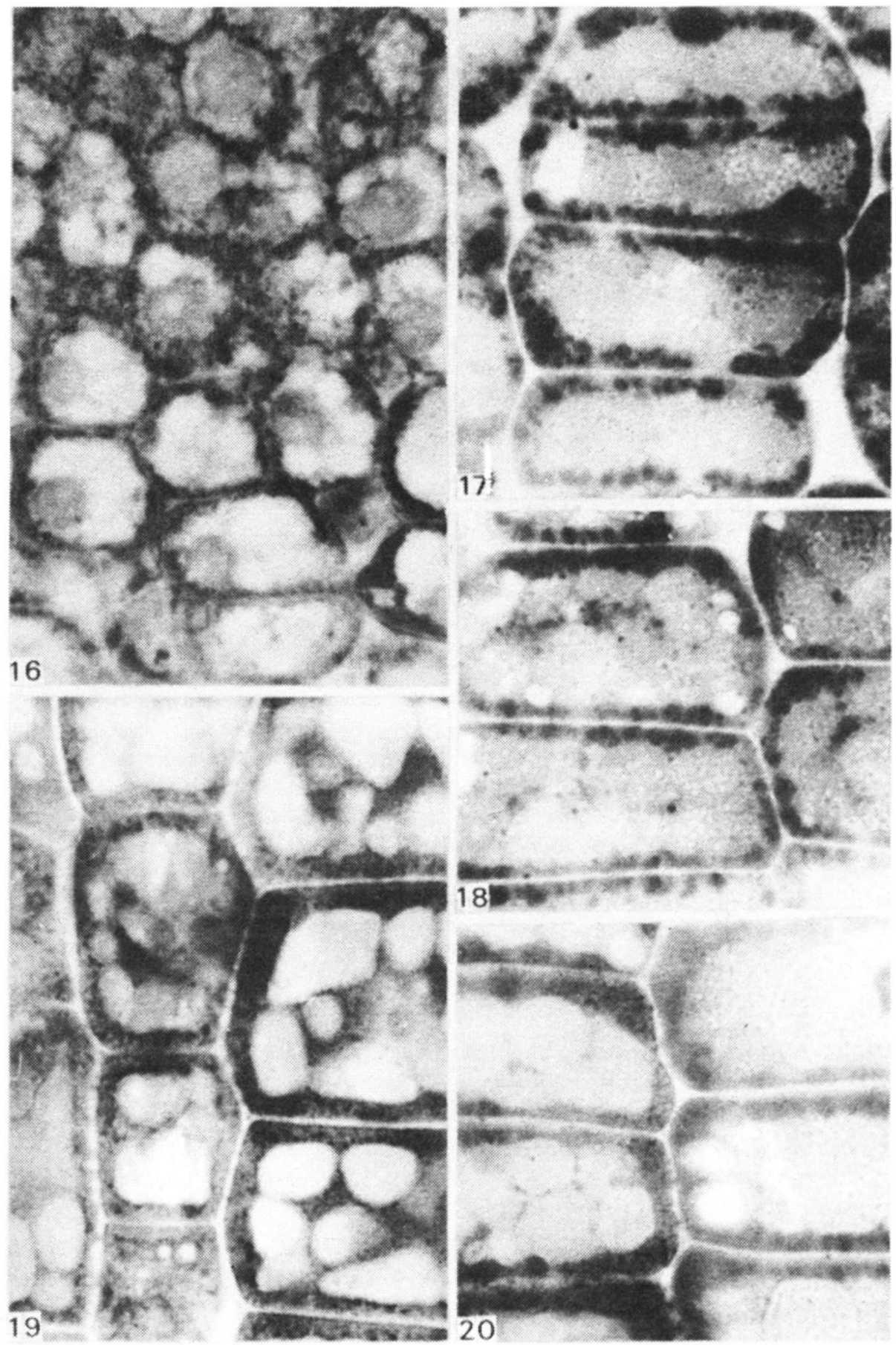


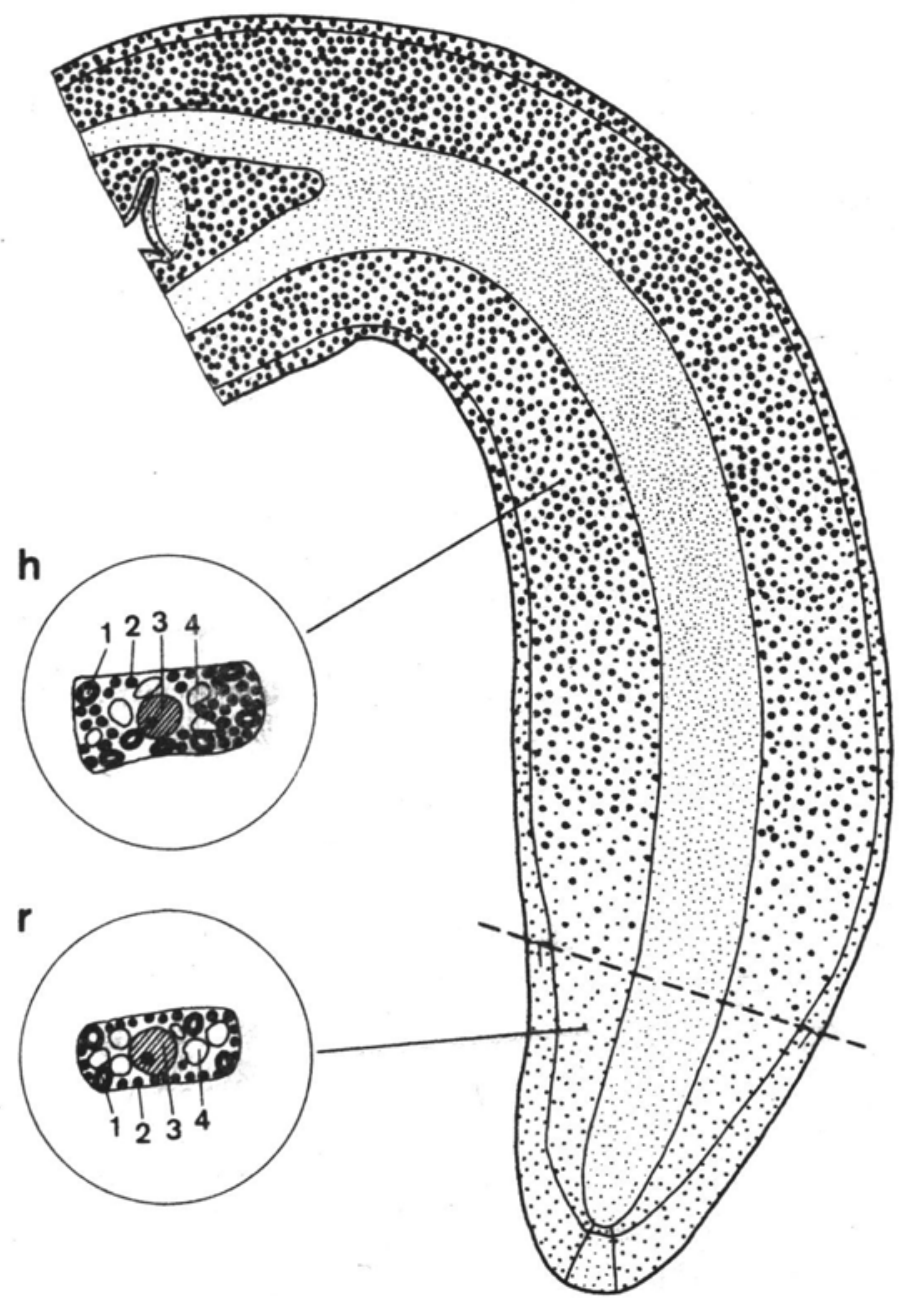

Fig. 21. Diagram of embryo axis at the final embryogenesis stage. Dots indicate embryo lipid bodies, $\mathrm{h}$ - hypocotyl periblem cell, $\mathrm{r}$ - radicle periblem cell: 1 - starch in chloroplast, 2 - lipid body, 3 - nucleus with nucleolus, 4 - vacuole

apices are the least of all changed. Lipid bodies translocate and often form many layers, next to the cell wall (Figs. 17, 19, 20). It seems that lipid bodies are more abundant now than at the previous stage.

In browning seeds the number of lipid bodies increases so that they surround protein bodies (Fig. 20). At the same time the nucleus becomes lobate. Between nucleus lobes protein bodies surrounded by lipid bodies occur.

Lipid bodies loose gradually their affinity to osm (Figs. 13, 20). In black seeds, and often earlier, they are not stainable with osm.

These changes occur more or less in the whole embryo exis. Rape embryo isolated from black seeds has been throughly described by Kuraś (1984). 


\section{DISCUSSION}

Lipid bodies accumulate in developing and maturating embryo. They have been already observed in two-celled proembryo. Probably they occur in rape zygote like in zygote of Capsella (Schultz and Jensen 1968a). Basal cell in two-celled embryo contains more lipid bodies. The most abundant lipid bodies occur in three-celled embryo, then they rapidly decline and reappear later starting from the torpedo stage (Schultz and Jensen 1968b).

The present studies indicate that lipid bodies occur in the whole course of rape proembryo development. Their number increase in globular embryo and during its transformation into heart stage, when both endosperm and embryo become green (Tykarska 1982). Kavetskaya (1960) has observed distinct oil droplets in 14-day-old embryo (according to Tykarska (1980) these embryos are at heart and torpedo stages). She has also noticed that in 30-days-old embryo the cytoplasm starts to fill up with oil. According to Tykarska (1980), the seed colour changes as well. From the present studies it may be inferred that lipid oodies change at the same time. Spherical before, they become less regular and they do not stain black with osm. Frey-Wyssling et al. (1963) have described in rape cytoledons the transformation of lipid bodies, so called spherosomes, into transparent fat bodies.

A similar process in the development of Sinapis seeds is, according to Rest and Vaughan (1972), "a change in the nature of the oil connected with the developmental age of the embryo". This has been confirmed by many biochemical studies on maturing seeds of some cultivars of erusic rape (e.g. Górczański variety). It has been found that the concentration of erusic acid inreases during seed maturation (Sims 1964, Zeman and Kratochwil 1967, Fowler and Downey 1970, Wiązecka and Krzymański 1970, Norton and Harris 1975). Zeman and Kratochwil (1967) have inferred that the synthesis of long-chain fat acids becomes intensified. According to Norton and Harris (1975) these are typical storage triglycerides. At the same time the authors have noticed a decrease in the concentration of short-chain acids. In rape the latter are usually unsaturated, often with several double bounds. According to Pearse (1968) unsaturated acids stain black with osm.

Therefore, it may be concluded that lipid bodies in maturing embryos are typical storage lipids of mature seeds, whereas lipid bodies in young embryos form metabolic material used either as an energy source for cell divisions (Schultz and Jensen 1968b), or in the formation of typical storage lipids. Probably, starch can be also the storage material for the lipid formation; it hydrolizes and declines in maturing rape embryos (Kavetskaya 1960, Norton and Harris 1975, Tykarska 1982). 
In this paper both number and size of lipid bodies have been estimated only due to their apparent differences among different parts of embryo axis. Size and number of lipid bodies decrease both along the embryo axis from its part below cotyledons towards root apex radially inwards.

\section{REFERENCES}

Adams C. A., Shong Wan Norby, Rinne R. W., 1983. Ontogeny of lipid bodies in developing soybean seeds. Crop Science 23: 757-759.

Baker J. R., 1946. The histochemical recognition of lipine. Quart. J. Microscop. Sci. 87: 441.

Bair C. W., Snyder H. E., 1980. Electron microscopy of soybean lipid bodies. J. Amer. Oil Chem. Soc. 57: 279-282.

Bergfeld R., Hong Y. N., Kuhnl and Schopfer P., 1978. Formation of oleosomes (storage lipid bodies) during embryogenesis and their breakdown during seedling development in cotyledons of Sinapis alba L., Planta 143: 297-307.

Chiffelle T. L., Putt F. A., 1951. Propylene and ethylene glycol as solvents for Sudan IV and Black B. Stain Technol. 26: 51-56.

Fowler D. B., Downey R. K., 1970. Lipid and morphological changes in developing rapeseed. Brassica napus. Can. J. Plant Sci. 50: 233-247.

Frey-Wyssling A.,' Grieshaber E., Muhlethaler K., 1963. Origin of spherosomes in plant cells. J. Ultrastr. Res. 8: 506-516.

Kavetskaya J. O., 1960. Embriologiya rapsa i dinamika nakopleniya zapasnykh vieshchestv v simieni. Nauchn. Trudy Ukr. Acad. Selskokh. Nauk 10: 111-119.

Kuraś M., 1984. Activation of embryo during rape (Brassica napus L.) seed germination. III. Ultrastructure of dry embryo axis. Acta Soc. Bot. Pol. 53: 171-186.

La Cour L. F., Chayen J., Gahan P. S., 1958. Evidence for lipid material in chromosomes. Exp. Cell Res. 14: 469-485.

Lison L., 1960. Histochimie et cytochimie animales. Gauthier-Villars. Paris.

Norton G., Harris J. F., 1975. Compositional changes in developing rapeseed (Brassica napus L.). Planta 123: 162-174.

Pearse A. G. E., 1968. Histochemistry theoretical and applied. Third ed., J \& A Churchill Ltd., London.

Rest J. A., Vaughan J. G., 1972. The development of protein and oil bodies in the seed of Sinapis alba L. Planta 105: 245-262.

Schultz S. R., Jensen W. A., 1968a. Capsella embryogenesis: the egg. zygote and young embryo. Amer. J. Bot. 55: 807-819.

Schultz S. R., Jensen W. A., 1968b. Capsella embryogenesis: the early embryo. J. Ultrastr. Res. 22: 376-392.

Sims R. P. A., 1964. Changes in the fatty acid composition of the seeds of three oil bearing species during increasing seed maturity. Can. J. Plant Sci. 44: 217-218.

Svieshnikova J. N., 1954. O vozniknovienii zhira v krakhmalnykh ziernakh. Dok. Akad. Nauk SSSR 95: 889-892.

Tykarska T., 1980. Rape embryogenesis. III. Embryo development in time. Acta Soc. Bot. Pol. 49: 369-385.

Tykarska T., 1982. Rape embryogenesis. IV. Appearance and disappearance of starch during embryo development. Acta Soc. Bot. Pol. 51: 381-387.

Wiązecka K., Krzymański J., 1970. Zmiany w składzie chemicznym rzepaku ozimego w czasie ich formowania i dojrzewania. Hod. Rośl. Aklim. 14: 291-308.

Zeman I., Kratochwil V., 1967. Changes in the composition of winter rape oil during seed maturation. Biol. Plant. 9: 1-14. 


\section{Embriogeneza rzepaku. V. Gromadzenie cial lipidowych}

\section{Streszczenie}

W zarodku rzepaku ozimego, od stadium dwukomórkowego prazarodka, obserwowano ciała lipidowe w mikroskopie świetlnym. Ich liczba i wielkość wzrasta w czasie embriogenezy, zwłaszcza od okresu zazielenienia się bielma i zarodka. Ciała lipidowe, pojedyncze i w skupieniach, są we wszystkich komórkach zarodka; skupiska tych ciał występują w różnych częściach cytoplazmy. W czasie dojrzewania zarodka ciała lipidowe przemieszczają się i są położone w wielu warstwach przy ścianie komórkowej. W tym czasie zmienia się wygląd ciał lipidowych. Powstają typowe lipidy zapasowe. Ciała lipidowe są rozmieszczone w zarodku nierównomiernie; wielkość i liczba ciał maleje wzdłuż osi zarodka od części podliścieniowej do wierzchołka korzenia. Na to nakłada się zróżnicowanie histologiczne; największe ciała są w epidermie i w korze, najmniejsze w walcu osiowym. Najmniej ciał lipidowych jest w kolumelli. 